\title{
Efficient small molecule-based bulk heterojunction photovoltaic cells with reduced exciton quenching in fullerene
}

\author{
Taojun Zhuang, Takeshi Sano , and Junji Kido ${ }^{*}$ \\ Department of Organic Device Engineering, Graduate School of Engineering, and \\ Research Center for Organic Electronics (ROEL), Yamagata University, Yonezawa, 992- \\ 8510, Japan \\ *Corresponding authors. E-mail: takeshi.sano@yz.yamagata-u.ac.jp (T. Sano); \\ kid@yz.yamagata-u.ac.jp (J. Kido).
}

Abstract: Most highly efficient small molecule-based bulk heterojunction (BHJ) photovoltaic cells contain a large concentration of fullerene in their blend active layers. However, the excitons generated in fullerene can seriously quench at the surface of the commonly used $\mathrm{MoO}_{3}$ buffer layer, becoming a key limitation to the photovoltaic performance of these cells. In this study, we've investigated various anode buffer layers in the thermally evaporated tetraphenyldibenzoperiflanthene (DBP) and $\mathrm{C}_{70}$-based $\mathrm{BHJ}$ cells with high $\mathrm{C}_{70}$ concentration. It's been found that obviously enhanced power conversion efficiency (PCE) of up to 6.26\% can be obtained in DBP and $\mathrm{C}_{70}$-based $\mathrm{BHJ}$ cells via simply replacing the $\mathrm{MoO}_{3}$ buffer by poly(3,4-ethylenedioxythiophene): poly(styrenesulfonate) (PEDOT: PSS), which is also a commonly used anode buffer 
material in polymer-based BHJ cells. Photoluminescence spectra results have confirmed the suppression of exciton quenching at the anode interface by inserting this PEDOT: PSS buffer. Moreover, after adding a $\mathrm{C}_{70}$ interlayer for better electron extraction and the further suppression of exciton quenching, the DBP and $\mathrm{C}_{70}$-based $\mathrm{M}-\mathrm{i}-\mathrm{n}$ photovoltaic cells show a remarkable PCE of $7.04 \%$ under illumination with $100 \mathrm{~mW} / \mathrm{cm}^{2}$, AM $1.5 \mathrm{G}$ simulated solar light.

Keywords: Organic photovoltaic; Fullerene; Anode buffer; Bulk heterojunction; Exciton quenching.

\section{Introduction}

Small molecule-based organic photovoltaic (OPV) cells have attracted great research interest over many years due to their potential as lightweight, low-cost, and flexible energy sources, and significant efforts have been devoted to develop various donor materials and device architectures to enhance their photovoltaic performance. In recent years, high power conversion efficiencies (PCEs) have been achieved by developing bulk heterojunction (BHJ) small molecule-based OPV cells with low donor concentration in a fullerene matrix via either thermal evaporation or solution processes.[1-7] The bulk heterojunction structure comprising a uniformly distributed donor/acceptor (D/A) blend active layer is beneficial for efficient exciton dissociation at the D/A interface.[1-3, 8-11] On the other hand, since the hole mobility of small molecule donors is usually much lower than the electron mobility of fullerene, employing a low donor ratio will give more balanced carrier transport in BHJ OPV cells, which can promote better charge extraction 
and reduce charge recombination in the blend active region.[4, 12, 13] In most small molecule-based BHJ OPV cells, especially the thermally evaporated ones, $\mathrm{MoO}_{3}$ is employed as the anode buffer layer due to its deep work function that is favorable for efficient hole-extraction.[3, 14] However, as previously reported, excitons generated in the fullerene may easily quench at the $\mathrm{MoO}_{3} /$ fullerene interface,[15] which becomes a key limitation to the photovoltaic performance in such BHJ OPV cells with a low donor ratio and high fullerene ratio.

In this study, we've demonstrated that largely improved photovoltaic performance of tetraphenyldibenzoperiflanthene (DBP) and $\mathrm{C}_{70}$-based $\mathrm{BHJ}$ OPV cells with high $\mathrm{C}_{70}$ concentration can be achieved through simply replacing the $\mathrm{MoO}_{3}$ anode buffer by poly(3,4-ethylenedioxythiophene): poly(styrenesulfonate) (PEDOT: PSS), which is an anode buffer material extensively used in polymer-based BHJ OPV cells.[10, 11] Photoluminescence (PL) spectra confirmed the suppression of exciton quenching at the interface of the $\mathrm{C}_{70}$ and PEDOT: PSS layers. With a PEDOT: PSS anode buffer layer, a PCE of $6.26 \%$ can be obtained in DBP and $\mathrm{C}_{70}$-based $\mathrm{BHJ}$ cells with enhanced external quantum efficiency $(\mathrm{EQE})$ and short-circuit current density $\left(\mathrm{J}_{\mathrm{sc}}\right)$ compared with those cells with a $\mathrm{MoO}_{3}$ buffer. In addition, after adding a $\mathrm{C}_{70}$ interlayer for further reduced exciton quenching in $\mathrm{C}_{70}$ and better electron extraction, the so-called M-i-n OPV cellsbased on DBP and $\mathrm{C}_{70}$ present an even higher PCE of up to $7.04 \%$ with an open-circuit voltage $\left(\mathrm{V}_{\mathrm{oc}}\right)$ of $0.88 \mathrm{~V}$, a fill factor (FF) of 0.59 , and a $\mathrm{J}_{\mathrm{sc}}$ of $13.4 \mathrm{~mA} / \mathrm{cm}^{2}$ under illumination of $100 \mathrm{~mW} / \mathrm{cm}^{2}$, AM $1.5 \mathrm{G}$ simulated solar illumination. 


\section{Experimental}

The materials used in our devices, including $\mathrm{MoO}_{3}, 1,4,5,8,9,11$-hexaazatriphenylene hexacarbonitrile (HAT-CN),[16] DBP,[17] $\mathrm{C}_{70}$, and bathocuproine (BCP) are commercially available. $\mathrm{MoO}_{3}$ and $\mathrm{BCP}$ were used as received. $\mathrm{C}_{70}$ and $\mathrm{DBP}$ were purified by multistep thermal sublimation. All the OPV devices were fabricated on indium-tin-oxide (ITO) coated glass substrates. The substrates were precleaned using deionized water, acetone and isopropanol under sonication and then treated with UVozone for 30 min prior to use. $\mathrm{MoO}_{3}, \mathrm{C}_{70}, \mathrm{BCP}$, and the $\mathrm{Al}$ cathode were deposited via thermal evaporation under high vacuum at base pressure of $\sim 5 \times 10^{-5} \mathrm{~Pa}$. PEDOT: PSS films of $30 \mathrm{~nm}$ thickness were prepared via spin coating. The Al cathode was deposited through a shadow mask, and the overlap between the ITO anode and the Al cathode defined an active area of $3 \times 3 \mathrm{~mm}^{2}$. After the deposition of the $\mathrm{Al}$ cathode, the devices were transferred directly to a nitrogen-filled glove box for encapsulation without exposure to air. The EQE and current density-voltage $(\mathrm{J}-\mathrm{V})$ characteristics were measured by an integrated characterization system for thin film solar cells, CEP-2000 by Bunkoukeiki Co. The PCE was measured under $100 \mathrm{~mW} / \mathrm{cm}^{2}$ illumination of AM $1.5 \mathrm{G}$ solar spectrum. A reference silicon diode with a KG-5 filter certified by the National Institute of Advanced Industrial Science and Technology in Japan was used to calibrate incident light intensity. Absorption spectra were measured by a SHIMADZU MPC-2200 UV-visible spectrophotometer. Surface roughness profiles were measured with AFM (Veeco). The HOMO levels of the fullerene materials were determined using Riken Keiki AC-3. The LUMO levels were then derived by subtracting the optical band gaps from the HOMO levels. The PL spectra were obtained using a commercial spectrophotometer 
equipped with a standard solid sample holder, and all of the samples were prepared on precleaned glass substrates. The excitation wavelength for PL measurements is $467 \mathrm{~nm}$.

\section{Results and discussion}

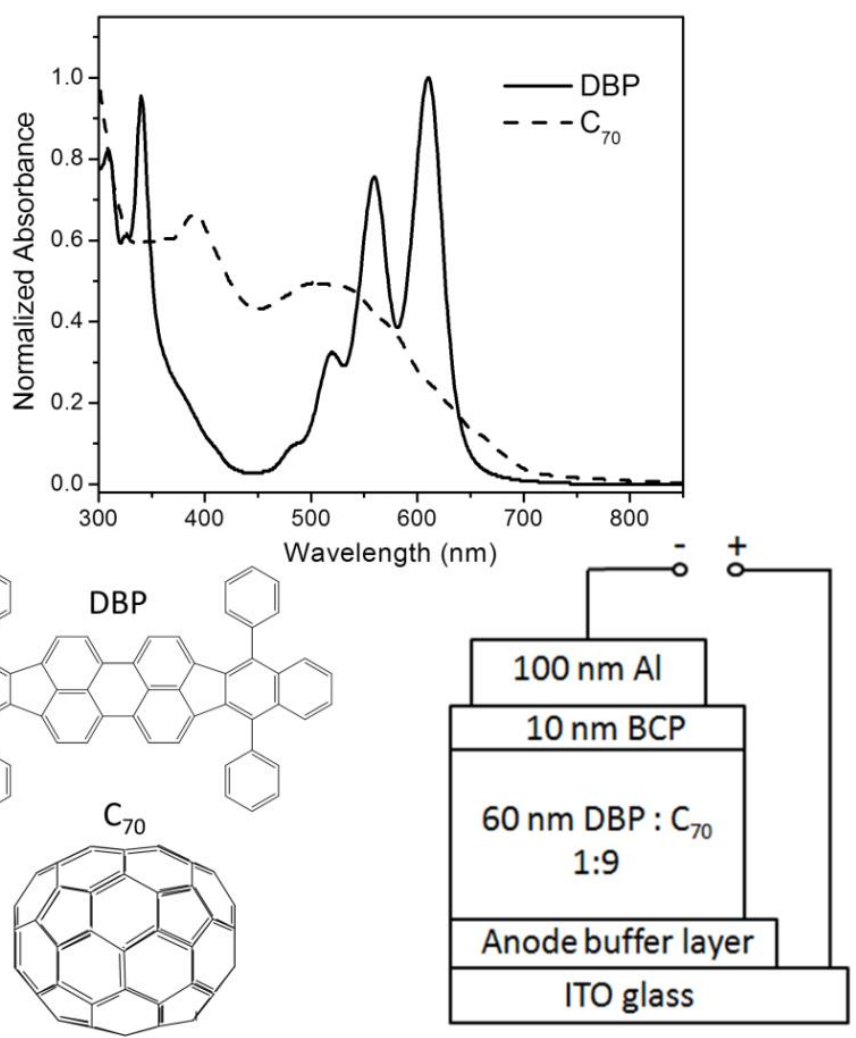

Fig. 1 The normalized absorption spectra of $\mathrm{DBP}$ and $\mathrm{C}_{70}$, their chemical structures and the device architecture of DBP and $\mathrm{C}_{70}$-based $\mathrm{BHJ}$ cells with various anode buffer layers.

First, DBP and $\mathrm{C}_{70}$-based $\mathrm{BHJ}$ cells with various anode buffer layers are investigated. Fig. 1 depicts the normalized absorption spectra of DBP and $\mathrm{C}_{70}$, their chemical structures and the device architecture of $\mathrm{BHJ}$ cells in the following discussion. $\mathrm{C}_{70}$ exhibits two intense absorption bands in the whole visible wavelength range, while the absorption of DBP is strong in the wavelength range from 500 to $600 \mathrm{~nm}$. The blend active layer in the DBP and $\mathrm{C}_{70}$-based $\mathrm{BHJ}$ cells is set to $60 \mathrm{~nm}$ thickness with the ratio of $1: 9$, based on 
many reports on such BHJ systems.[5-7, 14, 15] Therefore, $\mathrm{C}_{70}$ in the blend active layer contributes to most of the absorption in the wavelength range from 300 to $700 \mathrm{~nm}$ and DBP only covers a part of the absorption in the wavelength range from 500 to $600 \mathrm{~nm}$. Fig. 2 shows $\mathrm{J}-\mathrm{V}$ curves of $\mathrm{DBP}$ and $\mathrm{C}_{70}$-based $\mathrm{BHJ}$ cells using different anode buffer layers and the corresponding EQE spectra. Table 1 lists the key parameters in all these BHJ cells. Voc values in the BHJ cells using different anode buffer layers are similar since these devices are based on the same DBP and $\mathrm{C}_{70}$ system, where $\mathrm{V}_{\mathrm{oc}}$ is mainly decided by the difference between HOMO of DBP and LUMO of $\mathrm{C}_{70}$. A PCE of 5.65\% has been achieved in the DBP and $\mathrm{C}_{70}$-based $\mathrm{BHJ}$ cell with $\mathrm{MoO}_{3}$ buffer, which is in consist with previously reported results. $[6,15]$ Compared with the $\mathrm{BHJ}$ cell using $\mathrm{MoO}_{3}$ buffer, the BHJ cell with PEDOT: PSS buffer exhibits a significantly enhanced $\mathrm{J}_{\mathrm{sc}}$ $\left(\sim 12.50 \mathrm{~mA} / \mathrm{cm}^{2}\right)$, which corresponds to the improvement of EQE response at the midwavelength range, where $C_{70}$ has a strong absorption coefficient (from 450 to $550 \mathrm{~nm}$ ). FF and $\mathrm{V}_{\mathrm{oc}}$ values in $\mathrm{BHJ}$ cells with $\mathrm{MoO}_{3}$ or PEDOT: PSS buffers are close therefore the BHJ cell with PEDOT: PSS buffer gives an improved PCE of $6.26 \%$. HAT-CN is an n-type organic semiconductor, but it can be used as the hole-extraction layer in organic light emitting devices.[18-20] Two-compound anode buffer layers, 5nm $\mathrm{MoO}_{3} / 5 \mathrm{~nm}$ HAT-CN and PEDOT: PSS/5 nm HAT-CN, are also employed in DBP: $\mathrm{C}_{70} \mathrm{BHJ}$ cells for comparison. It is interesting to note that the BHJ cells employing two-compound buffer layers show similar performance results. Their FF values are 0.54, slightly lower than those in BHJ cells with $\mathrm{MoO}_{3}$ or PEDOT: PSS buffer, which should be due to the increased series resistance after adding a $5 \mathrm{~nm}$ HAT-CN layer. $\mathbf{J}_{\mathrm{sc}}$ and PCE values in these BHJ cells with two-compound buffer layers are better than those of $\mathrm{MoO}_{3}$-based cells but 
worse than those of PEDOT:PSS-based cells, suggesting that the 5nm HAT-CN layer on top, in direct contact with the blend active layer, plays an essential role in the performance of these cells.
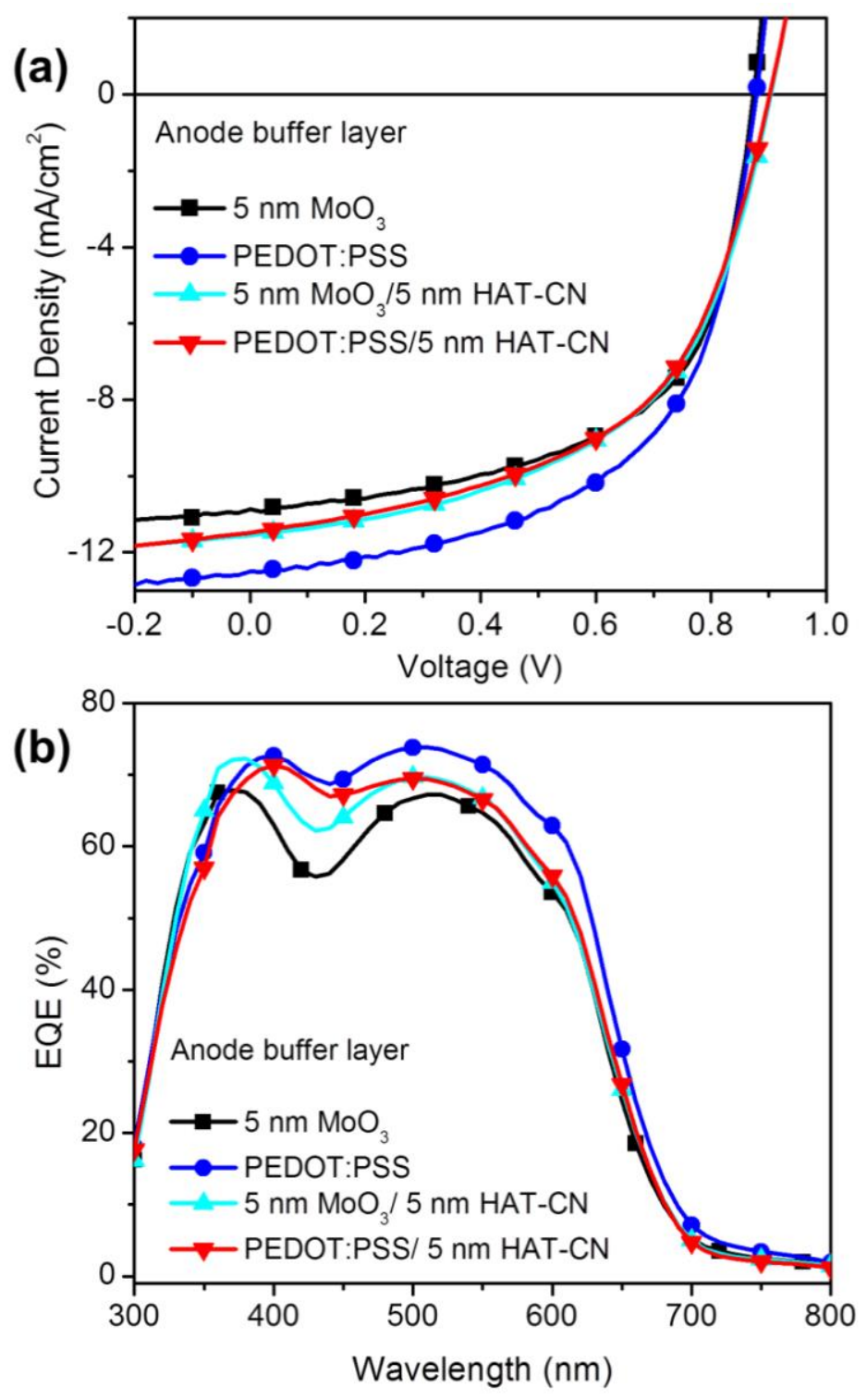

Fig. 2 (a) J-V curves of DBP and $\mathrm{C}_{70}$-based BHJ cells using different anode buffer layers and (b) the corresponding EQE spectra. 
Table 1 The key performance parameters obtained under simulated $100 \mathrm{~mW} / \mathrm{cm}^{2}$, AM $1.5 \mathrm{G}$ illumination from DBP and $\mathrm{C}_{70}$-based BHJ OPV devices with various anode buffer layers.

\begin{tabular}{ccccc}
\hline \hline Anode buffer layer & $\mathrm{J}_{\mathrm{sc}}\left(\mathrm{mA} / \mathrm{cm}^{2}\right)$ & $\mathrm{V}_{\mathrm{oc}}(\mathrm{V})$ & FF & PCE $(\%)$ \\
\hline $5 \mathrm{~nm} \mathrm{MoO}_{3}$ & 10.88 & 0.87 & 0.59 & 5.65 \\
PEDOT:PSS & 12.50 & 0.88 & 0.57 & 6.26 \\
5 nm MoO $/ 5 \mathrm{~nm} \mathrm{HAT-CN}$ & 11.56 & 0.90 & 0.54 & 5.59 \\
PEDOT:PSS/5 nm HAT-CN & 11.48 & 0.90 & 0.54 & 5.56 \\
\hline \hline
\end{tabular}

Next, we investigated if the buffer layer in direct contact with the blend active layer could have some influence on the morphology of DBP and $\mathrm{C}_{70}$-blend films, which leads to varied performance results of these BHJ cells with four different buffer layers. Fig. 3 shows AFM 3D images of $60 \mathrm{~nm}$ 1:9 DBP: $\mathrm{C}_{70}$ blend films deposited on the four different layers. It can be seen that the four films have similar RMS values, indicating that the morphology of the DBP: $\mathrm{C}_{70}$ blend film is hardly influenced by these buffer layers.
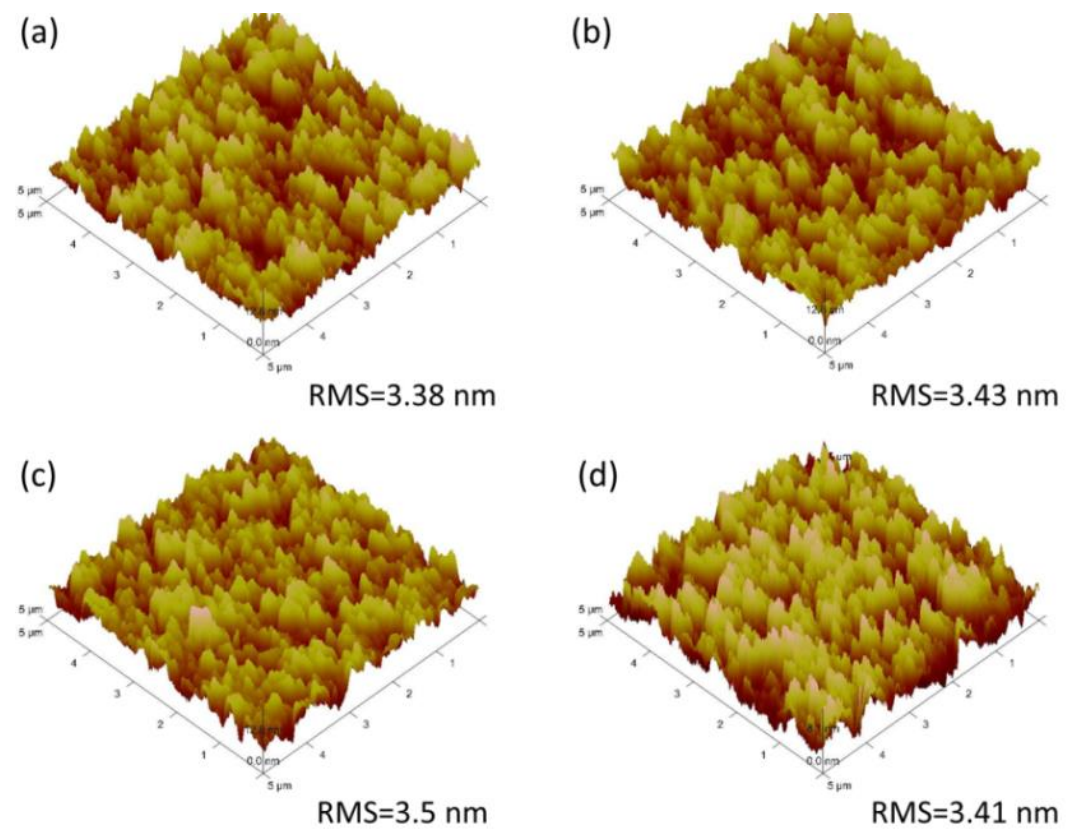


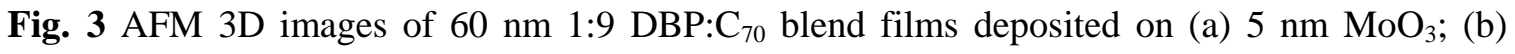
PEDOT:PSS; (c) $5 \mathrm{~nm} \mathrm{MoO} / 5 \mathrm{~nm}$ HAT-CN; (d) PEDOT:PSS/5 nm HAT-CN. The root-meansquare (RMS) shows the film roughness.

In our previous studies on fullerene donors, we demonstrated a charge transfer process occurring between $\mathrm{C}_{70}$ and HAT-CN.[16] In the BHJ cells with compound buffer layers, 5nm HAT-CN is in direct contact with DBP and the $\mathrm{C}_{70}$ blend active layer contains a high ratio of $\mathrm{C}_{70}$. Therefore, significant exciton quenching by charge transfer should occur at the HAT-CN/BHJ interface in these cells. In addition, some reports also show that excitons generated in the fullerene can easily quench at the $\mathrm{MoO}_{3} /$ fullerene interface.[15] Fig.4 presents the photoluminescence (PL) spectra of $20 \mathrm{~nm} \mathrm{C} \mathrm{C}_{70}$ film on top of different buffer layers $\left(\mathrm{MoO}_{3}\right.$, PEDOT: PSS, HAT-CN). We can see that $\mathrm{C}_{70}$ film on $\mathrm{MoO}_{3}$ gives the lowest PL peak, confirming that a large number of excitons generated in the $\mathrm{C}_{70}$ layer quench at the $\mathrm{MoO}_{3} / \mathrm{C}_{70}$ interface. In comparison, excitons quench much less at the PEDOT: PSS/C 70 interface. These PL results are consistent with the performance results of BHJ cells with various anode buffer layers, which show a great improvement in photocurrent by simply introducing PEDOT: PSS buffer. Another point to mention is the optical spacer effect caused by the PEDOT: PSS layer. Because the thickness of PEDOT: PSS is around $30 \mathrm{~nm}$, which is much thicker than other buffer layers, it can change the optical field distribution through the device and move the peak of the absorbed optical power at long wavelengths into the photoactive region,[12] leading to a red shift of the EQE spectra of BHJ cells based on PEDOT: PSS buffer. This optical effect also contributes to the improvement of $\mathrm{J}_{\mathrm{sc}}$. 


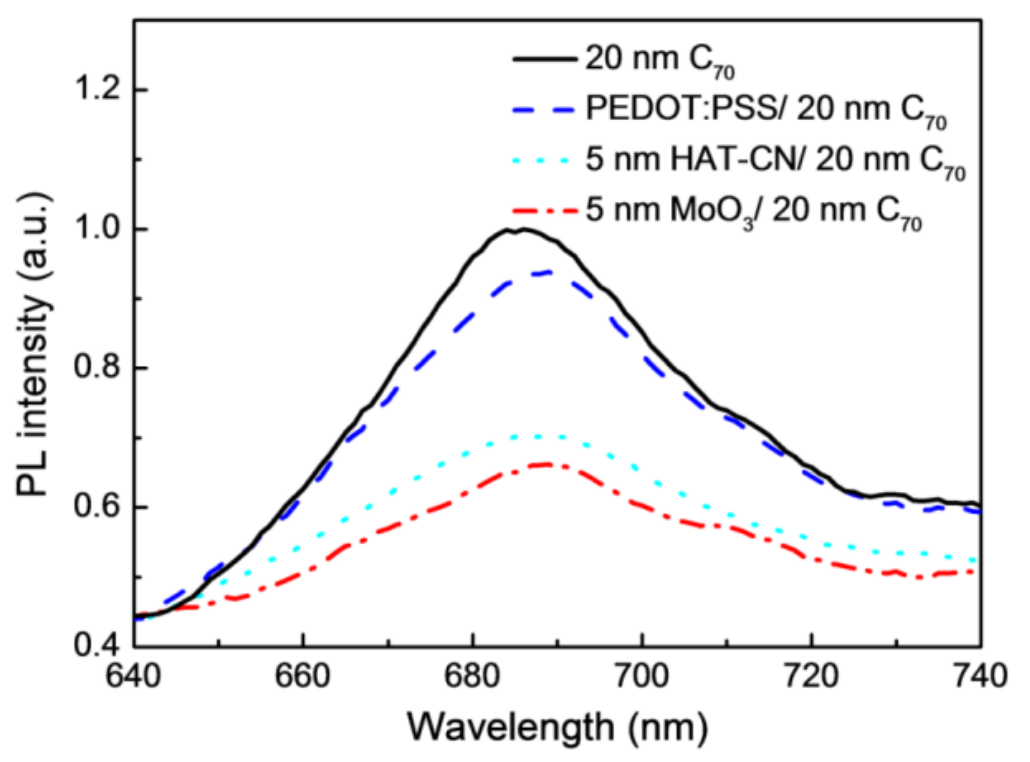

Fig. 4 Photoluminescence (PL) spectra of $20 \mathrm{~nm} \mathrm{C}_{70}$ on different anode buffer layers.

So far, a reduced exciton quenching in DBP: $\mathrm{C}_{70}$ BHJ cells using PEDOT: PSS instead of $\mathrm{MoO}_{3}$ has been demonstrated and a high PCE of $6.26 \%$ can be obtained with a $\mathrm{J}_{\mathrm{sc}}$ of $12.50 \mathrm{~mA} / \mathrm{cm}^{2}, \mathrm{~V} \mathrm{~V}_{\mathrm{oc}}$ of $0.88 \mathrm{~V}$ and a FF of 0.57 . To further improve the performance, a $\mathrm{C}_{70}$ interlayer is employed in DBP and $\mathrm{C}_{70}$-based $\mathrm{BHJ}$ cells to form so-called M-i-n cells. The introduction of the $\mathrm{C}_{70}$ interlayer can both improve electron extraction and reduce exciton quenching at the buffer/BHJ surface by changing the optical field distribution.[5, 15] Therefore, as shown in Fig. 5, after inserting this $C_{70}$ interlayer, $J_{s c}$ in the M-i-n cell with PEDOT: PSS buffer is further enhanced $\left(\sim 13.43 \mathrm{~mA} / \mathrm{cm}^{2}\right)$, resulting in a remarkably high PCE of up to $7.04 \%$ (depicted in Table 2). 

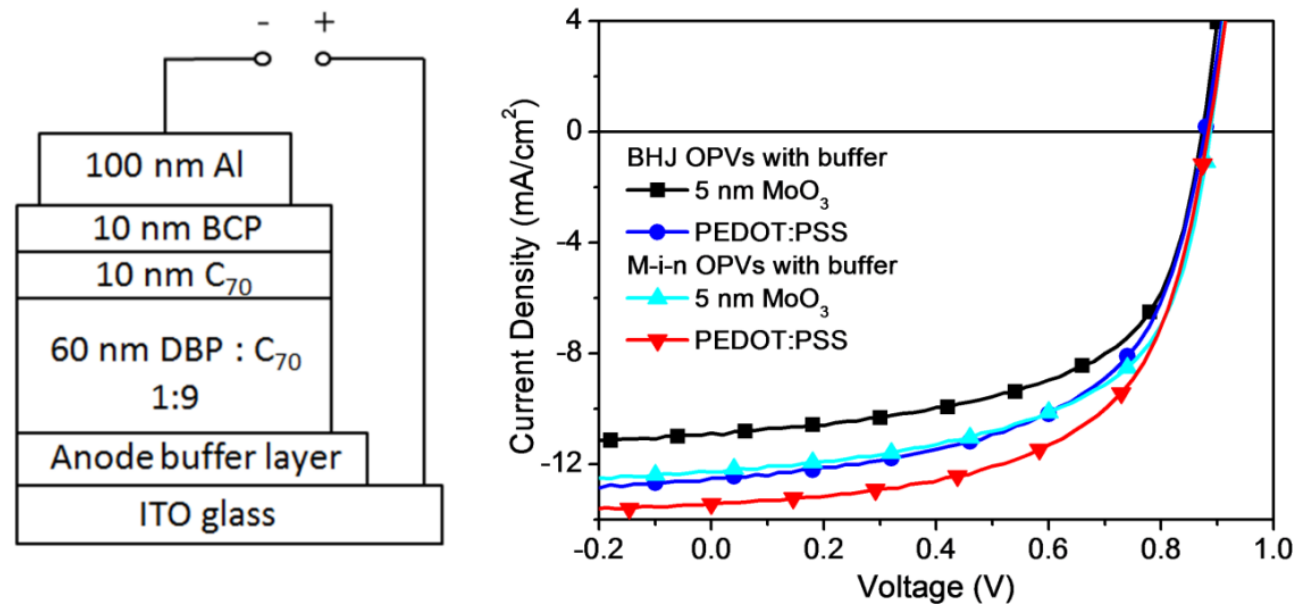

Fig. $5 \mathrm{~J}-\mathrm{V}$ curves of DBP and $\mathrm{C}_{70}$-based $\mathrm{BHJ}$ and $\mathrm{M}-\mathrm{i}-\mathrm{n}$ cells employing PEDOT: PSS buffer or $\mathrm{MoO}_{3}$ buffer. The device structure of M-i-n cells is also given.

Table 2 The key performance parameters obtained under simulated $100 \mathrm{~mW} / \mathrm{cm}^{2}$, AM $1.5 \mathrm{G}$ illumination from DBP and $\mathrm{C}_{70}$-based BHJ or M-i-n OPV devices with two anode buffer layers.

\begin{tabular}{cccccc}
\hline \hline Structure & Anode buffer layer & $\begin{array}{c}\mathrm{J}_{\mathrm{sc}} \\
\left(\mathrm{mA} / \mathrm{cm}^{2}\right)\end{array}$ & $\mathrm{V}_{\mathrm{oc}}(\mathrm{V})$ & FF & $\begin{array}{c}\text { PCE } \\
(\%)\end{array}$ \\
\hline \multirow{2}{*}{$\mathrm{BHJ}$} & $5 \mathrm{~nm} \mathrm{MoO}_{3}$ & 10.88 & 0.87 & 0.59 & 5.65 \\
& $\mathrm{PEDOT:PSS}^{*} \mathrm{M}-\mathrm{i}-\mathrm{n}$ & 12.50 & 0.88 & 0.57 & 6.26 \\
& $5 \mathrm{~nm} \mathrm{MoO}$ & 12.28 & 0.89 & 0.58 & 6.38 \\
& PEDOT:PSS & 13.43 & 0.88 & 0.59 & 7.04 \\
\hline \hline
\end{tabular}

\section{Conclusion}

To achieve high efficiency in BHJ OPV cells, exciton quenching must be avoided. Considering the high concentration of fullerene in the blend layer of many efficient small molecule-based BHJ cells and the fact that excitons generated in fullerene can seriously quench at the surface of the commonly used $\mathrm{MoO}_{3}$ buffer layer, we employ another buffer material PEDOT: PSS, which is commonly used in polymer-based BHJ OPV cells, to improve the performance of small molecule-based BHJ OPV cells. In the DBP and $\mathrm{C}_{70}$-based BHJ cells with a ratio of $1: 9$, an enhanced PCE of $6.26 \%$ has been obtained by 
simply using PEDOT: PSS buffer instead of $\mathrm{MoO}_{3}$. PL spectra results have confirmed the suppression of exciton quenching at the anode interface by inserting the PEDOT: PSS buffer layer. After adding a $\mathrm{C}_{70}$ interlayer for better electron extraction and further suppression of exciton quenching, the DBP and $\mathrm{C}_{70}$-based M-i-n OPV cells can present a remarkable PCE of $7.04 \%$ under illumination of $100 \mathrm{~mW} / \mathrm{cm}^{2}$, AM $1.5 \mathrm{G}$ simulated solar illumination. These results show there's much room for the improvement of photovoltaic performance in small molecule-based BHJ OPV cells by reducing exciton quenching in fullerene.

\section{Acknowledgements}

We thank the Japan Science and Technology Agency via the Japan Regional Innovation Strategy Program by the Excellence (J-RISE) for financial support.

\section{References}

[1] S. Uchida, J. Xue, B.P. Rand, S.R. Forrest, Organic small molecule solar cells with a homogeneously mixed copper phthalocyanine: $\mathrm{C}_{60}$ active layer, Appl. Phys. Lett., 84 (2004) 4218-4220.

[2] J. Xue, B.P. Rand, S. Uchida, S.R. Forrest, A Hybrid Planar-Mixed Molecular Heterojunction Photovoltaic Cell, Adv. Mater., 17 (2005) 66-71.

[3] M. Zhang, H. Wang, H. Tian, Y. Geng, C.W. Tang, Bulk Heterojunction Photovoltaic Cells with Low Donor Concentration, Adv. Mater., 23 (2011) 4960-4964.

[4] G. Chen, H. Sasabe, Z. Wang, X.-F. Wang, Z. Hong, Y. Yang, J. Kido, CoEvaporated Bulk Heterojunction Solar Cells with >6.0\% Efficiency, Adv. Mater., 24 (2012) 2768-2773. 
[5] X. Xiao, K.J. Bergemann, J.D. Zimmerman, K. Lee, S.R. Forrest, Small-Molecule Planar-Mixed Heterojunction Photovoltaic Cells with Fullerene-Based Electron Filtering Buffers, Adv. Energ. Mater., 4 (2014) 1301557.

[6] Y.-q. Zheng, W.J. Potscavage, T. Komino, C. Adachi, Highly efficient bulk heterojunction photovoltaic cell based on tris[4-(5-phenylthiophen-2-yl)phenyl]amine and C70 combined with optimized electron transport layer, Appl. Phys. Lett., 102 (2013) 153302.

[7] Y.-q. Zheng, W.J. Potscavage, T. Komino, M. Hirade, J. Adachi, C. Adachi, Highly efficient bulk heterojunction photovoltaic cells based on $\mathrm{C}_{70}$ and tetraphenyldibenzoperiflanthene, Appl. Phys. Lett., 102 (2013) 143304.

[8] T. Kaji, M. Zhang, S. Nakao, K. Iketaki, K. Yokoyama, C.W. Tang, M. Hiramoto, Co-evaporant Induced Crystalline Donor: Acceptor Blends in Organic Solar Cells, Adv. Mater., 23 (2011) 3320-3325.

[9] G. Li, V. Shrotriya, J. Huang, Y. Yao, T. Moriarty, K. Emery, Y. Yang, Highefficiency solution processable polymer photovoltaic cells by self-organization of polymer blends, Nat. Mater., 4 (2005) 864-868.

[10] H.-L. Yip, A.K.Y. Jen, Recent advances in solution-processed interfacial materials for efficient and stable polymer solar cells, Energ. Environ. Sci., 5 (2012) 5994-6011.

[11] L. Lu, T. Xu, W. Chen, E.S. Landry, L. Yu, Ternary blend polymer solar cells with enhanced power conversion efficiency, Nat. Photon. 8 (2014) 716-722.

[12] P. Peumans, A. Yakimov, S.R. Forrest, Small molecular weight organic thin-film photodetectors and solar cells, J. Appl. Phys., 93 (2003) 3693-3723.

[13] A. Mishra, P. Bäuerle, Small Molecule Organic Semiconductors on the Move: Promises for Future Solar Energy Technology, Angew. Chem. Int. Ed., 51 (2012) 20202067.

[14] Z. Wang, D. Yokoyama, X.-F. Wang, Z. Hong, Y. Yang, J. Kido, Highly efficient organic p-i-n photovoltaic cells based on tetraphenyldibenzoperiflanthene and fullerene $\mathrm{C}_{70}$, Energ. Environ. Sci., 6 (2013) 249-255.

[15] X. Xiao, J.D. Zimmerman, B.E. Lassiter, K.J. Bergemann, S.R. Forrest, A hybrid planar-mixed tetraphenyldibenzoperiflanthene/ $\mathrm{C}_{70}$ photovoltaic cell, Appl. Phys. Lett., 102 (2013) 073302. 
[16] T. Zhuang, X.-F. Wang, T. Sano, Z. Hong, G. Li, Y. Yang, J. Kido, Fullerene $\mathrm{C}_{70}$ as a p-type donor in organic photovoltaic cells, Appl. Phys. Lett., 105 (2014) 093301.

[17] D. Yokoyama, Z. Qiang Wang, Y.-J. Pu, K. Kobayashi, J. Kido, Z. Hong, Highefficiency simple planar heterojunction organic thin-film photovoltaics with horizontally oriented amorphous donors, Sol. Energ. Mat. Sol. C., 98 (2012) 472-475.

[18] C.E. Small, S.-W. Tsang, J. Kido, S.K. So, F. So, Origin of Enhanced Hole Injection in Inverted Organic Devices with Electron Accepting Interlayer, Adv. Funct. Mater., 22 (2012) 3261-3266.

[19] H.-W. Lin, W.-C. Lin, J.-H. Chang, C.-I. Wu, Solution-processed hexaazatriphenylene hexacarbonitrile as a universal hole-injection layer for organic lightemitting diodes, Org. Electron., 14 (2013) 1204-1210.

[20] L.S. Liao, W.K. Slusarek, T.K. Hatwar, M.L. Ricks, D.L. Comfort, Tandem Organic Light-Emitting Diode using Hexaazatriphenylene Hexacarbonitrile in the Intermediate Connector, Adv. Mater., 20 (2008) 324-329. 
